\title{
HRM ZA TOP MANAGEMENT \\ 19. junija 2007 na Brdu pri Kranju
}

$\mathrm{D}$

evetnajstega junija je $\mathrm{v}$ organizaciji Planet GV na Brdu pri Kranju potekalo prvo srečanje $\mathrm{z}$ obetavnim naslovom HRM za TOP MANAGEMENT, kjer so organizatorji želeli predstaviti aktualne tematike s področja ravnanja z ljudmi pri delu in izmenjati pomembne izkušnje na tem področju $\mathrm{z}$ vodilnim slovenskim managementom.

V strokovnem uvodu je dr. Daniela Brečko, direktorica Planeta GV, predstavila osrednjo dilemo slovenskega managementa: imamo sicer vrhunske managerje, ki odlično obvladujejo ekonomijo, vse bolj pa primanjkuje pravih novodobnih vodij. Ob tem je predstavila definicijo managementa, torej upravljanja, in definicijo vodenja. Upravljanje je povezano z delegiranjem, strateškim načrtovanjem, preskrbo z viri, organizacijo dela ... torej s stvarmi, za katere lahko trdimo, da so železni repertoar vsakega managerja, in zanje tudi vselej vemo, kako in kdaj se jih lotiti. Toda vodenje, ki je nepogrešljiv del vsakega upravljanja, je vodenje ljudi $\mathrm{v}$ smeri zastavljenih ciljev in vključuje »mehke dejavnike«, kot so vizioniranje, komuniciranje ciljev, navduševanje, motiviranje, reševanje konfliktov ... Po mnenju svetovnih strokovnjakov za razvoj managementa je vodenje $\mathrm{v}$ času globalne konkurence in spremenjenih vrednot celo veliko pomembnejše kot zgolj upravljanje. In s slednjim dejstvom se je na posvetu strinjala tudi večina slovenskih managerjev ter njihovih najožjih kolegov kadrovskih strokovnjakov. Organizator je namreč na posvet spretno povabil najvišje vodilne in njihove najožje kadrovske sodelavce (vodje kadrovskih služb) z namenom, da se vname tudi diskusija o tem, kakšne vloge naj bi igrali prvi in drugi $\mathrm{v}$ organizacijah $\mathrm{z}$ namenom, da bi od zaposlenih pridobili kar največ dodane vrednosti za organizacijo.

In s čim se torej ubadajo novodobni managerji pri ravnanju z ljudmi pri delu? Dr. Daniela Brečko je izpostavila, da so to predvsem štiri stvari:

- delovni čas,

- fleksibilnost zaposlitve,

- intenzivnost dela in

- zadovoljstvo z delom.

Pri podajanju konkretnih številk se je opirala na rezultate EIRO študije o delovnih razmerah, 2007, v kateri je sodelovala tudi Slovenija ter slovenski strokovnjak dr. Ivan Svetlik. V raziskavi je sodelovalo 31 držav (članice EU in Turčija, Hrvaška, Norveška ter Švica).

\section{Delovni čas}

Delovni čas se spreminja in cela Evropa išče nove načine, kako bi lahko s pomočjo fleksibilnega delovnega časa povečala učinkovitost. Čeravno zgolj delovni čas nikoli ni bil merilo prave učinkovitosti, pa je vseeno zanimiva primerjava trajanja delovnega časa v Sloveniji in Evropski uniji, ki jo prikazujemo $\mathrm{v}$ tabeli 1.

Kot je razvidno iz tabele, Slovenci delamo na teden več, kot znaša evropsko povprečje, prav tako pogosteje delamo ob sobotah in nedeljah ter tudi izmensko. Le 22 odstotkov zapo- 
Tabela 1: Trajanje delovnega časa $v$ EU in Sloveniii

\begin{tabular}{|l|c|c|}
\hline & $\begin{array}{c}\text { EU } \\
\text { (27 držav) }\end{array}$ & SLO \\
\hline delovni teden & 38 ur & 42 ur \\
\hline celotni delovni čas & 58 ur & 65 ur \\
\hline ob sobotah & $53 \%$ & $59 \%$ \\
\hline ob nedeljah & $28 \%$ & $36 \%$ \\
\hline izmensko delo & $17 \%$ & $23 \%$ \\
\hline gibljivi delovni čas & $\begin{array}{l}\text { Skandina- } \\
\text { vija } 59 \%\end{array}$ & $22 \%$ \\
\hline
\end{tabular}

Tabela 2: Fleksibilnost zaposlitve in intenzivnost dela

\begin{tabular}{|l|c|c|}
\hline & EU (27 držav) & SLO \\
\hline $\begin{array}{l}\text { zaposlitev za } \\
\text { nedoločen čas }\end{array}$ & $78 \%$ & $75 \%$ \\
\hline $\begin{array}{l}\text { plačilo } \\
\text { po normi/kosu }\end{array}$ & min. 1\% & $\begin{array}{c}\text { več kot v Sloveniji le še } \\
\text { v 6 državah: }\end{array}$ \\
\hline $\begin{array}{l}\text { RO; CZ; LT; EE; IT; SK } \\
\text { plačilo nadur }\end{array}$ & min. 0 & $\begin{array}{c}45 \% ; \\
\text { več le v IT in CZ }\end{array}$ \\
\hline $\begin{array}{l}\text { intenzivnost } \\
\text { dela }\end{array}$ & & \\
\hline indeks 1-60) & 44 & $54 ; 1.2000$ 23, \\
& & \\
\hline
\end{tabular}

slenih ima gibljivi delovni čas, kar nas znova uvršča precej nižje, kot je povprečje EU, kjer sicer prednjači Skandinavija s kar 59 odstotki zaposlenih z gibljivim delovnim časom.

\section{Fleksibilnost zaposlitve in intenzivnost dela}

Iz pričujoče tabele je razvidno, da v Sloveniji plačujemo veliko nadur in da ima še vedno 19 odstotkov zaposlenih normirano delo, kar nas uvršča na sam rep držav EU. Še posebej pa je zaskrbljujoč podatek, da indeks intenzivnosti dela precej narašča, saj je $\mathrm{v}$ petih letih poskočil kar za 29 indeksnih točk in je leta 2005 znašal torej 54 indeksnih točk, kar je za celih 10 točk več, kot znaša povprečje v EU. Torej bi lahko rekli, da smo se ujeli v klasično dilemo med uspešnostjo in učinkovitostjo, oziroma bomo morali poiskati načine, kako $\mathrm{z}$ manj porabljene energije narediti izdelek $\mathrm{z}$ višjo dodano vrednostjo, saj samo delo še ni garancija za uspeh.

\section{Zadovoljstvo z delom}

Podatki prikazujejo presenetljivo razmišljanje Slovencev, da delo škodljivo vpliva na zdravje, torej Slovenci kar v 62 odstotkih menimo, da je delo vir bolezni. Prednjačimo tudi pri bolniških odsotnostih. Podatek je precej zaskrbljujoč, saj očitno dela ne sprejemamo kot vira osebnostnega razvoja, ampak kot breme, ki kvarno vpliva na naše psihično in fizično zdravje. Morebiti je to še zapuščina tranzicijskega obdobja in kot taka bolj značilna za tranzicijske države. Izziv, ki čaka tako managerje kot tudi njihove kadrovske kolege, so torej delovne vrednote in povečanje zadovoljstva $\mathrm{z}$ delom.

Vprašanja, ki se torej kar sama postavljajo pred top management, so:

- Kako torej naši zaposleni percepirajo delo?

- Smo še vedno v tranziciji?

- Je delo še osnovna vrednota Slovencev?

- Ali lahko še nadalje pospešujemo intenzivnost dela? 
Tabela 3: Zadovoljstvo z delom

\begin{tabular}{|c|c|c|}
\hline & $\begin{array}{c}\text { EU } \\
\text { (27 držav) }\end{array}$ & SLO \\
\hline $\begin{array}{l}\text { delo vpliva na } \\
\text { zdravje }\end{array}$ & $35 \%$ & $62 \%$ \\
\hline bolniški dopust & $\begin{array}{c}32 \% \mathrm{v} \\
\text { povprečju } \\
21 \mathrm{dni}\end{array}$ & $\begin{array}{c}40 \% \mathrm{v} \\
\text { povprečju } \\
32 \mathrm{dni}\end{array}$ \\
\hline $\begin{array}{l}\text { število dni } \\
\text { bolniške na } \\
\text { delavca }\end{array}$ & 4,5 & 8,7 \\
\hline $\begin{array}{l}\text { zadovoljstvo z } \\
\text { delom (terciarna } \\
\text { izobrazba) }\end{array}$ & $81 \%$ & $71 \%$ \\
\hline terciarna izobrazba & $\begin{array}{c}39 \% \text {; najv. } \\
\text { DK, NL, } \\
\text { FI, SE }\end{array}$ & $\operatorname{pod} 20 \%$ \\
\hline
\end{tabular}

- Delamo prave stvari?

- Ravnamo z ljudmi strateško?

O slednjih vprašanjih so udeleženci razpravljali na dveh omizjih. Prvo je nosilo naslov Korporativna kultura, delovne vrednote in vloga vodilnega managementa, $\mathrm{ki}$ ga je zelo spretno vodil Brane Gruban, na njem pa so sodelovali Biljana Weber, predsednica uprave IBM Slovenija, mag. Sonja Klopčič iz Trima Trebnje, dr. Daniela Brečko, direktorica Planeta GV, Silva Globačnik, direktorica področja organizacije v Gorenju, in mag. Robert Ličen, direktor Steklarne Rogaška. Sogovorniki so predstavili zanimive primere grajenja korporativne kulture in delovnih vrednot skozi različne oblike fleksibilnega zaposlovanja, nagrajevanja $\mathrm{v}$ obliki bonitet ter možnosti osebnega razvoja, ki ga podjetja nudijo posamezniku. Še zlasti so bili zanimivi tudi primeri transferja znanja za dvig korporativne kulture ter posebne oblike organiziranosti projektnih timov ter timskih mrež v smislu zasledovanja prepletenosti in soodvisnosti posameznikov ter s tem dviga ravni organizacijske klime. Vsi sogovorniki so si bili edini, da je nepogrešljiv graditelj organizacijske klime prav vodja, ki te vloge ne more prenesti na druge. Pri tem so sogovorniki tudi poudarili, da lahko organizacijsko kulturo kot element razvoja delovnih vrednost začnemo v podjetju razvijati šele, ko imajo zaposleni zadovoljene primarne psihološke potrebe oz. doseženo minimalno materialno varnost.

\section{IMAJO SLOVENSKI MANAGERJI DOVOLJ ENERGIJE ZA VODENJE?}

Planet GV je v mesecu aprilu 2007 izvedel tudi raziskavo Organizacijske energije $v$ slovenskih podjetjih, s katero je ugotovil, da se kar 34 odstotkov slovenskih organizacij giblje $\mathrm{v}$ polju korozivne energije, kjer prevladujejo pesimizem, konflikti, destruktivna vedenja in posledično neučinkovitost. Le v 25 odstotkih podjetij je zaznati produktivno energijo, prevladujejo dinamični in sodelujoči odnosi ter kar vrvi od idej in ambicij. Preostale slovenske organizacije pa so se znašle v polju udobne inertnosti, kjer ljudje počivajo na preteklih lovorikah, in v polju ravnodušne inertnosti, kjer med zaposlenimi prevladuje mišljenje, da so neranljivi in niso del tržnih razmer ter je pomanjkanje ambicij ter ustvarjalnosti skorajda popolno.

Managerji imajo v tistih podjetjih, kjer prevladujejo korozivna energija, udobna inertnost ali ravnodušna inertnost, vsekakor veliko težje delo pri izgrajevanju organizacijske kulture kot managerji, ki delujejo v organizacijah, kjer prevladuje produktivna energija.

In ravno o tem vprašanju, torej vprašanju vodenja, smo spregovorili na drugem omizju z naslovom Finančni in kadrovski vidik rasti podjetja - kaj je pomembnejše: vodenje ali upravljanje, ki ga je vodil Mitja Cimerman, sodelovali pa so Romana Pajenk, 
Graf 1: Organizacijska energija v slovenskih organizacijah

Vir: Raziskava Organizacijska energija, Planet GV, 2007

\section{PROPORCIONALNA RAZDELITEV ENERGIJE V SLOVENSKIH ORGANIZACIJAH}

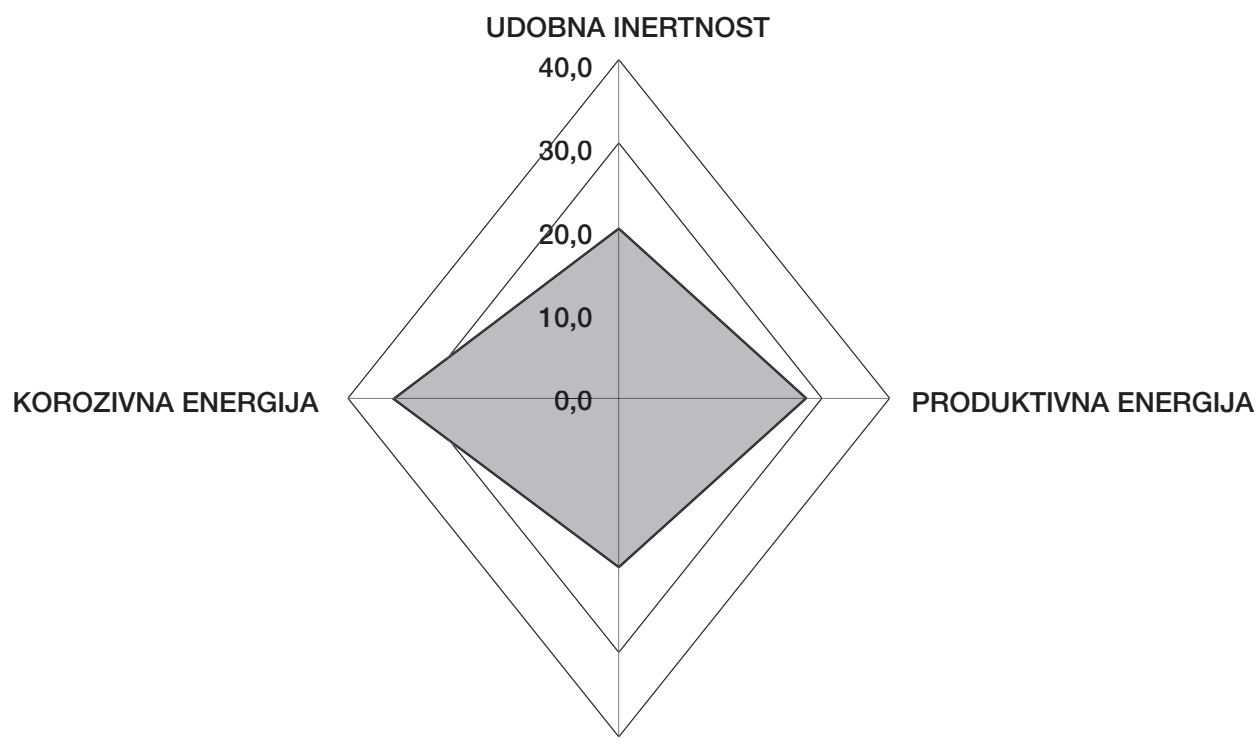

RAVNODUŠNA INERTNOST

predsednica uprave Probanke, Zofija Mazej

Kukovič, (bivša) predsednica uprave Esotecha, Jurij Giacomelli, član uprave Prve pokojninske družbe, in Janez Poje, član uprave Kovinoplastike Lož.

Sogovorniki so se načeloma strinjali, da je težje kot finančno rast zagotoviti kadrovsko rast podjetja, oziroma da finančna rast velikokrat prehiteva kadrovsko. Vodenje za razliko od upravljanja tako postaja vsak dan pomembnejše. Prav s procesi vodenja odkrivamo talente $\mathrm{v}$ organizaciji, jih spodbujamo, opogumljamo tudi za tvegane odločitve in motiviramo.

$\mathrm{Z}$ vidika konkurenčnosti organizacije je namreč sila pomembno vprašanje, koliko imate »tigrov«? Koliko imate uspeha lačnih ljudi? Kajti zemljevid konkurenčnosti bodo pisali majhni: tisti, ki so lačni uspeha, in tisti, ki so motivirani. Zato je lahko danes dobro organizirano podjetje neuspešno, kaotično z visoko motiviranimi ljudmi pa uspešno. Sogovorniki so si bili edini, da njihove organizacije potrebujejo več »tigrov«, torej uspeha željnih ljudi z ambicijami, ki bodo gnali organizacije naprej in imajo jasne cilje, kaj želijo doseči na poti poklicne kariere.

Glavno spoznanje prvega tematskega posveta HRM ZA TOP MANAGEMENT je bilo, da se morajo vodje vsekakor več ukvarjati z ljudmi in več časa kot do sedaj namenjati vodenju in ne zgolj upravljanju. Novodobni vodje potrebujejo veliko energije za delo $\mathrm{z}$ ljudmi, še zlasti pa visok nivo čustvene in socialne inteligentnosti.

Prav tako je bil eden izmed temeljnih zaključkov posveta vzpostavitev tesnejšega sodelovanja med top managementom in kadrovskimi strokovnjaki, ki morajo pri oblikovanju ter vodenju HRM procesov stopati 
z roko v roki. Managerji bi želeli še večji poudarek dati svetovalni vlogi kadrovske službe. Na strani kadrovske službe pa se je čutilo delno pomanjkanje strateških znanj HRM, da bi to vlogo lahko tudi kakovostno izpeljali. Toda sogovorniki na omizjih so dokazali, da imamo v Sloveniji že nekaj odličnih praks tako na področju top managementa kot tudi na področju strateške podpore kadrovske službe, ki lahko služijo kot odlični primeri za vsa druga podjetja. Ta bodo slej kot prej morala postaviti procese HRM v ospredje in središče poslovnih procesov, oziroma jim vsekakor nameniti več pozornosti. S tem namenom bo organizator junija naslednje leto pripravil 2. posvet HRM za top management.

*Poročilo s posveta je bilo z dovoljenjem objavljeno tudi v reviji HRM!

dr. Daniela Brečko 